\title{
Catch, bycatch and discards of the Galapagos Marine Reserve small-scale handline fishery
}

Johanna S Zimmerhackel, Anna C Schuhbauer, Paolo Usseglio, Lena C Heel, Pelayo Salinas-de-León

Fisheries bycatch is a significant marine conservation issue as valuable fish are wasted and protected species harmed with potential negative ecological and socio-economic consequences. Even though there are indications that the small-scale handline fishery of the Galapagos Marine Reserve has a low selectivity, information on its bycatch has never been published. We used onboard monitoring and interview data to assess the bycatch of the Galapagos handline fishery by estimating the bycatch ratio, determining species compositions of landings and bycatch, identifying fishers' reasons for discarding certain individuals, and revealing historical trends in the bycatch ratio. The estimated bycatch ratio as a function of biomass of 0.40 and a diverse species composition of target catch and bycatch confirmed the low selectivity of this fishery. Most individuals were not landed for economic motivations, either because species $(77.4 \%)$ or sizes $(17.7 \%)$ are unmarketable or for regulatory reasons (5.9\%). We found that bycatch contributes to growth overfishing of some target species because they are discarded or used as bait before reaching their first maturity. Moreover, over half of interviewees perceived a historical decrease in bycatch ratios that was explained by a diversification of the target catch due to the reduction in abundance of the traditionally most important target species. As some target species show signs of overfishing and to date there are no specific regulations for the finfish fishery species in place, we recommend the implementation of a series of management measures to protect critical life stages of overexploited species and to improve the selectivity of the Galapagos handline fishery. 


\section{Authors:}

3 Johanna S. Zimmerhackel 1, *, Anna C. Schuhbauer 1, 2, Paolo Usseglio 3, 4, Lena C. Heel 1, 5, 6,

4 Pelayo Salinas-de-León 1

6 Affiliations:

71 Department of Marine Sciences, Charles Darwin Research Station, Puerto Ayora, Galapagos Islands,

8 Ecuador.

92 Fisheries Centre, Fisheries Economic Research Unit, The University of British Columbia, Vancouver,

10 British Columbia, Canada

113 Fisheries Ecology Research Lab, University of Hawaii at Manoa, Hawaii, USA

124 Fundación In-Nova, Toledo, Castilla la Mancha, Spain

135 Institute of Ecology and Environmental Chemistry, Leuphana University Lüneburg, Lüneburg,

14 Germany

156 Leibniz Center for Tropical Marine Ecology, Bremen, Germany.

16

17 * Corresponding author:

18 Johanna S. Zimmerhackel

19 Gottschedstrasse 13, 22301, Hamburg, Germany

20 Telephone: 00593-5-2526-146/147

21 E-mail: j.zimmerhackel@yahoo.de 


\section{Introduction}

The role of bycatch in global fisheries has become a significant marine conservation issue, especially in areas where serious ecosystem degradation has already been observed (Harrington, Myers \& Rosenberg, 2005). Bycatch is commonly referred to as the incidental catch of non-target species and is divided into the portion of the catch that is discarded because species or sizes are not marketable or of lower economic value (economic discards), and catch that is discarded due to regulatory restrictions (regulatory discards) e.g. protected species or certain sizes (Dunn, Boustany \& Halpin, 2011; National Marine Fisheries Service, 2011). Bycatch, when discarded, causes significant waste of natural resources and is of particular concern when the populations of the captured species are already severely overfished or threatened (Alverson, 1994; National Marine Fisheries Service, 2011). However, discards was proven to also have positive effects on the marine fauna that feeds on discards including lobsters, marine mammals, birds and sharks (Blaber \& Wassenberg, 1989; Wassenberg \& Hill, 1990; Saila, Nixon \& Oviatt, 2002; Bozzano \& Sardà, 2002; Grabowski et al., 2010). Bycatch has serious ecological consequences not just for the species caught, but also for entire marine ecosystems (Dayton et al., 1995; Crowder \& Murawski, 1998; Saila, Nixon \& Oviatt, 2002; Dulvy, Sadovy \& Reynolds, 2003; Kappel, 2005). Ecological impacts on community structure and fishery productivity are the result of increased fishing mortality of species that are important to shape the ecosystems such as species at high trophic levels (Myers et al., 2007; Shester \& Micheli, 2011) which can cause alterations in species assemblages and widespread community impacts via trophic cascades (Pauly et al., 1998; Lewison et al., 2004). In marine fisheries, bycatch implications include the negative economic impacts of foregone income due to discards of undersized individuals of commercially valuable species. Furthermore, the costs associated with discarding non-commercial species (Pascoe, 1997; Bjorkland, 2011; Dunn, Boustany \& Halpin, 2011), also includes the creation of a negative public image of fishers for wasting resources and for bycatching certain charismatic animals such as dolphins or marine turtles (Hall, 1999). Because of the high impact of bycatch in fisheries, Bjorkland (2011) stated that "the ecological, economic and social costs of bycatch in fishing activities are increasingly indefensible to governments, fishing interests, marine scientists and ocean activists", making it necessary to establish appropriate measures and finding alternative gear to successfully reduce the impact of bycatch on a global scale. 
63 Most bycatch studies have focused on industrial fisheries, leaving a lack of information regarding small-

64 scale fisheries, in particular towards effort, catch and bycatch (Lewison et al., 2004; Moore et al., 2010).

65 Small-scale fisheries are often described to be more selective and potentially more sustainable than

66 industrial fisheries and to be therefore the most sustainable option for the utilisation of coastal marine

67 resources (Chuenpagdee et al., 2006; Jacquet \& Pauly, 2008). However, recent studies show that

68 bycatch in small-scale fisheries can have severe ecological impacts, and if scaled to per-unit of total

69 catch they can be comparable to industrial fisheries (Soykan et al., 2008; Shester \& Micheli, 2011;

70 Parker \& Tyedmers, 2014). Moreover, small-scale fisheries are generally understudied and often

71 unregulated (Mora et al., 2009; Davies et al., 2009; Chuenpagdee, 2011). As small-scale fisheries

72 encompass $44 \%$ of the world's 50 million fishers and provide over half of the total global fisheries

73 production (Berkes, 2001; Chuenpagdee et al., 2006; Teh \& Sumaila, 2013), this knowledge gap

74 represents a major challenge to sustainable fisheries management and the conservation of threatened

75 species, especially in tropical fisheries of developing countries (Moore et al., 2010).

76

77

78

79

80

81

82

83

84

85

86

87

88

89

90

91

92

93

\section{The Galapagos handline fishery}

The Galapagos Archipelago did not have a consistent human presence until the 1930s (Reck, 1983; Danulat \& Edgar, 2002; Castrejón Mendoza, 2011). Since then, the highly productive and diverse marine ecosystems of the archipelago have been increasingly threatened by human activities, reflected by the exponential increase of the human population from 6,119 inhabitants in 1962 to 25,000 in 2010 (INEC, 2011), along with an increased of the number of tourists, which reached over 200,000 visitors per year in 2013 (DPNG, 2014). To ensure the sustainable economic development and protect the biodiversity of Galapagos, the 133,000 km² Galapagos Marine Reserve (GMR) was established in 1998. While industrial fishing was banned within the reserve, fishing rights were granted exclusively to the local small-scale fishing sector. The GMR was divided into functional zones including no take zones, where fishing activities are prohibited. These zones make up 18\% of the coastline (Heylings, Bensted-Smith \& Altamirano, 2002). Additionally, the implemented Organic Law for the Special Regimen for the Conservation and Sustainable Development of Galapagos (LOREG) includes regulations for iconic species such as sharks, marine mammals and sea horses, which are excluded from extractive activities, and if caught unintentionally, have to be returned to their natural environment. However, there is evidence that the established artisanal fishery caused major impacts upon fishing resources (Burbano et al., 2014; Schiller et al., 2014). The collapse of the sea cucumber 
94 fishery in the early 2000s represents the most severe example (Hearn, 2008; Wolff, Schuhbauer \& 95 Castrejón, 2012). The multispecies handline fishery (locally called "empate") is traditionally the most

96 important in Galapagos. Until the 1960s, fishers had no access to refrigeration and therefore preserved

97 fish by salting and drying it. Fish were then exported to the mainland where they formed the main 98 ingredient of "fanesca", a traditional Ecuadorian dish served at Easter. While presently the handline

99 fishery for fresh demersal finfish occurs all year round to supply local markets, the main market still

100 remains the exported salt-dried finfish to serve the ongoing demand for "fanesca", and is caught during 101 the hot season (December to April). The selectivity of the handline fishing method has been described

102 as both low for species and size ranges (Nicolaides et al., 2002; Peñaherrera \& Hearn, 2008), but

103 conversely also as fairly selective (Ruttenberg, 2001). However, to date no information on bycatch for

104 this fishery has been published. Studies have demonstrated that the handline fishery has caused an

105 impact on several exploited fish stocks, and revealed a dramatic shift in the volume of fish landings

106 and in the species composition of the handline fishery (Ruttenberg, 2001; Burbano et al., 2014; Schiller

107 et al., 2014). Despite the increasing evidence that there is a continuous trend of overexploitation of

108 target species, to date there has been no particular management plan in place for any of these species.

109 As the fishing sector sustains fishers' livelihoods and plays a significant role in the regional culture it is

110 crucial to prevent a further decline in the key target species, such as the regional endemic sailfin

111 grouper Mycteroperca olfax which is considered vulnerable on the IUCN red list of threatened species

112 (Castrejón Mendoza 2011). A better understanding of the complete catch of this fishery, including

113 bycatch species and their sizes, is therefore an important step towards a sustainable Galapagos handline 114 fishery.

115

\section{Aims of this study}

117 The aims of this study are to quantify the catch selectivity and bycatch ratios of the Galapagos handline

118 fishery. This information will help to establish a knowledge baseline from which changes in bycatch

119 ratios can be monitored and to inform decision making processes for future fisheries management

120 plans. We then analyse the social component of this multispecies fishery by identifying the fishers'

121 reasons for discarding certain individuals. Moreover, we hypothesize that changes in the availability of

122 key target species have resulted in changes in the fishers' decision making process of whether to keep

123 or discard a specimen. In order to test this hypothesis, we use interview surveys to evaluate historical

124 trends in the bycatch ratio and reasons for potential changes in bycatch levels. 
126 Materials and methods

127 Fishery observations

128 We monitored artisanal handline fishing trips with onboard observers from February to May 2012.

129 Fishers were asked for permission to take us on their fishing trips and a total of 62 fishers $(15.5 \%$ of all

130 Galapagos active fishers) in 14 fishing boats agreed on letting us on board. The handline technique

131 consists of a monofilament line weighted with lead and several short extensions of propylene line each

132 with one hook (Danulat \& Edgar, 2002). Fishing depths ranged from 15 to $200 \mathrm{~m}$, with trip durations

133 lasting from one to two days and an average duration of 8 hours $(\mathrm{SD}=6.5)$. Departure and arrival date

134 and time, vessel horsepower and number of fishers on board were recorded for each trip. During each

135 fishing trip, fishers actively looked for promising bottom structure and fished for several minutes on

136 selected sites before moving to the next. We recorded the effective fishing time at each of these sites as

137 the interval starting when the first line was cast and ending when the last line was out of the water. Start

138 and stop time, geographical position, number of hooks and lines in the water, number of fishers, water

139 depth, bait and capture time were recorded at each site. The study area with all monitored fishing sites is

140 shown in Fig. 1. Total lengths of all individuals were recorded and converted to weight using available

141 length-weight relationships (Froese \& Pauly, 2000). If no length-weight relationship was available, these

142 were obtained by means of regression analysis on our catch data as suggested by Lima-Junior et al.

143 (2002). Whenever a species could not be identified by observers and fishers, we took a picture of the

144 individual and identified the species on land with the help of local fishery experts and Fishbase.org

145 (Froese \& Pauly, 2000). Catch was categorized according to the bycatch definition of the US National

146 Marine Fisheries Service (MSA 1996), such that all individuals that are either sold or used for personal

147 consumption are categorized as landings, while all other individuals are bycatch. We furthermore

148 distinguished different bycatch categories between bycatch survival (individuals that were discarded

149 alive) and bycatch mortality (individuals that were discarded dead or used as bait). Additionally, the

150 condition of individuals when released was recorded and their release observed. Whenever possible, the

151 post-release mortality was noted, but could not be measured consistently for all discarded individuals.

152

153 Bycatch estimates

154 Landings and bycatch were expressed as numbers of individuals and biomass (kg). Additionally, for

155 each of the defined landing and bycatch categories, biomass percentages were calculated. The bycatch 
156 ratio (BCR) is defined as the ratio of bycatch to total catch, whereby total catch equals landings plus

157 bycatch. $\mathrm{BCR}$ was obtained as a function of abundance $\left(\mathrm{BCR}_{\mathrm{N}}\right)$ and biomass $\left(\mathrm{BCR}_{\mathrm{W}}\right)$.

158

159

160

161

162

163

164

165

166

167

168

169

170

171

172

173

174

175

176

177

178

179

180

181

182

183

\section{Species composition}

Species composition is shown as numbers of species categorized as landings or bycatch. We identified three reasons for fishers not landing an individual, and divided the bycatch accordingly into the three subcategories: species that are not lucrative because they have low or no market value were defined as "not marketable species", small sized and therefore not lucrative individuals of otherwise marketable species were defined as "not marketable sizes", and bycatch of protected species was defined as "regulatory discard". We report the average Total Length (TL) of each species represented in these categories as well as the bycatch ratio of each species $\left(\mathrm{BCR}_{\mathrm{S}}\right)$, defined as the ratio in which the number of individuals of each species belong to the bycatch.

\section{Prediction of bycatch sizes}

For exploited species for which an adequate sample size was obtained $(\mathrm{n} \geq 100)$, a logistic regression model was used to estimate the probability of a fish being landed based on its size. Fish TL was summarized into $5 \mathrm{~cm}$ length categories. Proportion of fish considered as landed was calculated for each length category. The model followed the formula:

$\operatorname{Logit}(\mathrm{p})=\frac{p}{1-p}$

where 1-p is the probability of that a given fish would not be landed. Confidence intervals of the parameters of the regression were estimated via bootstrapping with 100 iterations. Analyses were done using the R package FSA (Ogle, 2013a). The resulting predictive model was used to estimate the size below which a fish would have an $80 \%$ probability of becoming bycatch $\left(\mathrm{b}_{80}\right)$. We furthermore obtained the odds ratio of the model, which is the factor by which the probability of an individual to be landed increases with each $5 \mathrm{~cm}$ in TL. The $\mathrm{b}_{80}$ value was compared to the mean length at which species reach first maturity $\left(\mathrm{L}_{\mathrm{m}}\right)$. $\mathrm{L}_{\mathrm{m}}$ was estimated from the maximum length $\left(\mathrm{L}_{\max }\right)$ of the species using the following formula as suggested by Froese \& Binohlan (2000).

$\log (10) \mathrm{L}_{\mathrm{m}}=-0.2713+\log (10) \mathrm{L}_{\max } * 1.0260$ 
$184 \mathrm{~L}_{\max }$ was obtained from Fishbase for $C$. princeps $(102 \mathrm{~cm})$. For $P$. albomaculatus $(65 \mathrm{~cm})$ and $P$.

185 clemensi $(61 \mathrm{~cm})$ we used the $\mathrm{L}_{\max }$ of our own data set because it was higher than the published $\mathrm{L}_{\max }$

186 from Fishbase.

187

188 Interview surveys

189 To obtain additional information about bycatch species and historical changes in bycatch composition

190 and quantities, a total of 100 semi-structured interviews with fishers from Santa Cruz (26\%) and from

191 San Cristobal (74\%) Islands were conducted representing approximately 25\% of the 400 active fishers

192 in the GMR. Because of the close relationship the fishers have with their environment, we used their

193 experience and knowledge, as this information can fill important knowledge gaps including the

194 abundance of fish stocks and perceived historical changes in the fishery (Johannes, Freeman \&

195 Hamilton, 2000; Murray, Neis \& Johnsen, 2006; McCluskey \& Lewison, 2008). From April to May

196 2012, we approached fishers from Santa Cruz and San Cristobal Islands and asked them for permission

197 to carry out in-person interviews. Because interviewers had already worked closely with fishers and

198 guaranteed their anonymous status, it was possible to gain the fishers' trust. Therefore no fishers

199 rejected the participation and answers are believed to be reliable. To avoid any influence on fishers'

200 responses, interviews were carried out with one fisher at a time. Interviewed fishers were asked to

201 suggest fellow fishers who could be interviewed, who we then approached at the fishing dock in order

202 to ask their participation in the interview. Our use of this snowball sampling technique (Goodman,

203 1961) helped ensure that an adequate number of interviews $(n \geq 78, N=400$, confidence level $=95 \%$

204 and margin of error $=10 \%$ ) were completed. In order to identify species that are commonly caught as

205 bycatch, we asked fishers: "Can you name species that you discard or use as bait while fishing with

206 handlines?" We furthermore asked: "For what reason do you not land these species?". A Pearsons' chi

207 square test was used to test for interactions among the answers given and the island of residence of the

208 fishers.

209

210 Additionally, we asked fishers about their perceptions of historical changes with the questions: "Do

211 you perceive any changes in the amount of individuals that you either discard or use as bait during your

212 working life?", "Did the bycatch ratio decrease, increase or stayed the same?" and "Please give an

213 explanation for your perception."We used an open interview as it has been proven to provide a much

214 more detailed description of the answers provided (Jackson \& Trochim, 2002). Answers about most 
215 common bycatch species, reasons for not landing these species, historical changes in bycatch and

216 reasons for changes given by fishers were manually coded, each code representing one explanation that

217 fishers gave. We chose this approach because answers to open questions can vary in the description

218 and human analysers are able to interpret the subtleties in answers to categorize and code them. We

219 then calculated the percentages of each coded answer.

220

221 The research was approved by the Galapagos National Park under the annual research plan of the

222 Charles Darwin Foundation (POA 2012, number 86).

223

224 Results

225 Bycatch estimates

226 A total of 22 fishing trips were conducted, resulting in 153 hours at sea and 94 hours of effective fishing 227 time. During fishing trips, 297 sites were visited and 1279 fish with a total combined biomass of 2.1

228 metric tonnes. Fractions of landing and bycatch categories are shown as a function of biomass in Fig. 2.

229 Total bycatch weighted $883 \mathrm{~kg}(\mathrm{n}=543)$, resulting in a $\mathrm{BCR}_{\mathrm{N}}$ of 0.43 and a $\mathrm{BCR}_{\mathrm{W}}$ of 0.40 .

230

\section{Landing composition}

232 We observed a total of 36 species caught by the Galapagos handline fishery. Landings were composed 233 of 17 fish species belonging to seven families. Of these, five species were landed exclusively and the 234 remaining 12 species were sometimes landed and sometimes discarded or used as bait. Landings were 235 dominated by fish of the family Serranidae, which was represented by eight species and made up for $23668 \%$ of the landed biomass. The Galapagos sailfin grouper (M. olfax) and the camotillo (Paralabrax 237 albomaculatus) were the most landed species constituting $40 \%$ and $13 \%$ of all landed biomass, 238 respectively. Other common target species were the ocean whitefish (Caulolatilus princeps) and the 239 mottled scorpionfish (Pontinus clemensi) representing 13\% and 10\% of the landed biomass, 240 respectively. While the first two species are fished in depths ranging from 15 to $40 \mathrm{~m}$, the latter two 241 species are targeted in deeper waters of up to $200 \mathrm{~m}$. Fishers used $7 \%$ of landed biomass for their 242 personal purposes which were represented by the five species (from highest to lowest occurrence) $C$. 243 princeps, $M$. olfax, P. clemensi, P. albomaculatus and the starry grouper Epinephelus labriformis.

244 Descriptive statistics of catch including the number of individuals per species, average size and bycatch 245 ratios are shown in Table 1. 
Bycatch composition and sizes

We found 31 species that were caught unintentionally, out of which 19 species were always discarded or used as bait. Out of the $43 \%$ of bycatch (number), we could distinguish between three different reasons for fishers not landing certain individuals: regulatory discards and individuals not marketable due to the species or their sizes. Regulatory discard included 26 juvenile sharks (23 Carcharhinus galapagensis and 3 Triaenodon obesus) as well as two sea lions (Zalophus wollebaeki). Protected species made up for $5.9 \%$ of all caught individuals as bycatch. Eighteen species were not landed because they were considered not marketable species constituting $77.4 \%$ of all caught individuals as bycatch. The most frequently caught unmarketable species were: the burrito grunt Anisotremus interruptus, the peruvian grunt Anisotremus scuderii, E. labriformis and the greybar grunt Haemulon sexfasciatum. Twelve species representing the remaining $17.7 \%$ of the bycatch were not landed because fishers considered the size of individuals too small to be economically valuable. The number of individuals per species caught as bycatch, average sizes and bycatch ratio are shown in Table 2.

The species $P$. albomaculatus, $C$. princeps and $P$. Clemensi were not only some of the most important target species in landings, they also were some of the most frequently caught bycatch species. Those three species made up five, four and two percent of all bycatch biomass, respectively. The biomass of $C$. princeps was mostly landed (79\%), but partly used as bait (19.6\%), partly discarded dead (1.2\%) and to a small extent discarded alive (0.6\%). Of the total biomass of $P$. albomaculatus, $76 \%$ was landed, $16.1 \%$ was used as bait, $8.0 \%$ discarded dead and only $0.9 \%$ was discarded alive. Finally, $75 \%$ of the caught biomass of $P$. clemensi was landed, $22.7 \%$ used as bait and $2.1 \%$ was discarded. No individuals of this species were discarded alive. An adequate sample size $(n \geq 100)$ for these three species allowed us to apply a logistic regression model which predicted the size below which individuals have a $80 \%$ chance to become bycatch. Results of this model are indicated in Fig. 4.

\section{Interview surveys}

The interviewed fishers' ages ranged from 19 to 80 years, with an average of 43.0 years $(\mathrm{SD}=11.9)$. While $42 \%$ of interviewed fishers were born in the Galapagos Islands, the remaining $58 \%$ were originally from mainland Ecuador. Of the 43 different species caught as bycatch, the reasons given for not landing 27 of these species was that they were not marketable species, whereas the other 14 were 
considered as bycatch when caught under a certain size to be marketable. Additionally, five of these species were discarded for both these reasons. Haemulidae (79\%) and Serranidae (37\%) were the most frequently mentioned families, represented by six and nine different species, respectively. The most common bycatch species mentioned by fishers were $A$. interruptus (39\%), A. scuderii (26\%), E. labriformis (24\%) and Sphoeroides annulatus (21\%). Furthermore, 73\% of fishers stated that they occasionally bycaught protected species. Of these, $68 \%$ identified sharks as bycatch with $29 \%$ of these were identified as $C$. galapagensis, $2 \%$ as Carcharhinus falciformes, $1 \%$ as $T$. obesus, while the remaining $36 \%$ did not specify the species. Rays were mentioned by $20 \%$ of fishers, turtles by $14 \%$, sea lions by $13 \%$ and marine birds by $3 \%$ (Fig. 3). There was no significant difference between the number of species reported by fishers from the two different islands of residence based on the Pearsons' chi square test $(\mathrm{p}=0.45)$

\section{Perception of historical changes of bycatch}

Results from interviews revealed that $52 \%$ of fishers perceived a decrease in bycatch throughout their working life mostly attributed to general decreases of fish abundance (44\%), shift in species composition of landings (21\%) or a change in their main fishing gear (13\%). On the other hand, eight percent of interviewees stated that they observed an increased amount of discards, which they explained with changes in fishing regulations. A third (31\%) of fishers stated that there was no change and $9 \%$ did not answer this question.

\section{Discussion}

This study provides the first insight into the selectivity of the Galapagos handline fishery. Our results suggest that Galapagos small-scale fisheries are not necessarily more selective than industrial fisheries as has been found elsewhere (e.g. Shester \& Micheli, 2011). We found the bycatch of the handline fishery to consist of a fairly diverse fish fauna where most specimens are discarded due to economic motivation, and to a lesser extent because of regulatory restrictions. Undersized individuals of some commercially exploited species suffer bycatch mortality contributing most probably to their overexploitation. Moreover, interviews revealed that the overexploitation of the commercial species caused a diversification of the catch composition which resulted in a historical change in the bycatch level towards lower bycatch ratios. 
309 The diverse catch composition of landed fish confirmed a low selectivity of this fishery and revealed that fishers consider a large part of their catch as target species. However, monitoring and previous

311 studies on this fishery focused mainly on the Galapagos sailfin grouper (Schiller et al., 2014). Given

312 the lack of attention on other exploited species and missing management measures for any fish species

313 in the GMR, most of the species caught are scarcely measured and poorly documented. A management

314 plan for these species is urgently needed and should take into consideration the multispecies character

315 of this fishery rather than focusing on single species management.

317 The overall bycatch of protected species recorded in this study was considerably low. However, results can be biased towards lower bycatch ratios and mortality caused by the observer effect, which occurs when fishers tend to follow a best practice fishing attitude during onboard monitoring, as opposed to un-observed fishers (Hall, 1999). Our results from both onboard observations and interview surveys confirm speculations that sharks are occasionally caught and discarded by the Galapagos handline fishery (Jacquet et al., 2008; Castrejón Mendoza, 2011). Sea lions scavenging around fishing gear increase their own susceptibility to incidental capture. The two by-caught sea lions got hooked on the fishing gear, while trying to feed on the captured fish and got injured because fishers hit them with a wooden plank with a nail attached to expel them. Even though this study did not detect any mortality of sharks and sea lions, there are indications that bycatch mortality of protected species occurs as sea lions are occasionally found dead, showing evidence of having died due to unnatural causes (Denkinger, Quiroga \& Murillo, 2014). Fishers see sharks and sea lions as competitors for marine resources and therefore as a threat to their livelihood (fishers, pers. comm.). Previous studies point out that discards of protected species might be under-reported, because fishers fear negative consequences when accurately reporting bycatch of these taxa (National Marine Fisheries Service, 2004; Lewison et al.,

332 2004). However, the high number of interviewed fishers who stated that they catch protected taxa by 333 accident, suggests that fishers answered our questions accurately.

\section{Bycatch estimates}

336 The estimated bycatch ratios of 0.40 (biomass) and 0.42 (numbers) are comparable to current global 337 fisheries bycatch estimates of 40.4\% (Davies et al., 2009). A study in Baja California, Mexico found 338 strong varying discard rates for different artisanal fishing gears $(0.11 \%$ for fish traps, $15.1 \%$ for lobster 
traps, 18.5\% for drift gillnet and 34.4\% for set gillnets) (Shester \& Micheli 2011). Even though the results of these studies are due to the assessments of different fishing techniques and species, and therefore not directly comparable with our results, it is interesting to note that the bycatch ratio of the Galapagos handline fishery is similar or higher than the ratios of the other fisheries studied. Species that suffered bycatch mortality consisted mostly of grunts and small sized individuals of economically valuable species. Bycatch of non marketable undersized individuals represents not only a waste of resources because specimens are being harvested before reaching their maximum yield per recruit, but it also contributes to growth overfishing of the most exploited species (Alverson, 1994). $P$. albomaculatus reaches first maturity at $36.3 \mathrm{~cm}$ TL which lays below the $\mathrm{b}_{80}$ of $39.2 \mathrm{~cm}$ indicating that there is no market for undersized individuals. However, immature individuals still suffer bycatch mortality because they are being used as bait which is of special concern, because $P$. albomaculatus is endemic to the Galapagos and classified as endangered on the IUCN red list of threatened species (Robertson et al., 2010). While the Lm and the b80 of P. clemensi is almost equal also indicating that fishers do not land immature individuals, the Lm of $C$. princeps was much higher than the b80. This is concerning because individuals are being landed before being able to reproduce which increases the chance for the population to suffer growth overfishing. The lack of knowledge about the biology of these species impedes a proper risk assessment, which is necessary for their effective management. Individuals that are discarded alive are still vulnerable as the interaction with the fishing gear can negatively affect the survival of the fish and lead to post-release mortality (Ryer, Ottmar \& Sturm, 2004). Among the reasons for this mortality are decompression sickness, deficits in swimming ability, feeding, and a higher vulnerability to predators (Davis, 2002). As delayed mortality was impossible to observe from onboard the fishing boat, the bycatch mortality might be higher than estimated here.

\section{Historical changes of bycatch}

Our results about historical changes of bycatch levels support signs of negative impacts on exploited species imposed by this handline fishery, which already go back to the 1980s (Reck, 1983; Nicolaides et al., 2002; Burbano et al., 2014; Schiller et al., 2014). The consequences are characterized by an alteration of the species assemblages in form of a strong decline in abundance and average size of apex-level fish, such as the targeted groupers (Reck, 1983; Bustamante, 1998; Nicolaides et al., 2002; Edgar et al., 2010; Schiller et al., 2014), which drives fishers to target more species and smaller sized fishes. Besides, consequences of the decline of top predators also affects marine communities as sites 
370 with high fishing pressure show a lower variability in the fish community structure indicating 371 significant changes in the functioning of coastal marine environments of the archipelago (Ruttenberg, 372 2001). Diversification of fishing gear and an increasing demand for fresh fish for local consumption 373 are also reasons for the diversification of target species and the decreasing fraction of groupers caught 374 with handlines within the finfish fishery of Galapagos (Castrejón Mendoza, 2011). This is supported by

375 376 377 378 379 380 seven percent of fishers who stated that their bycatch ratio decreased because they changed their fishing gear. Species like mullets (e.g. Xenomugil thoburni and Mugil galapagensis) caught with beach seine nets and pelagic species (e.g. Thunnus albacares and Acanthocybium solandri) caught trolling that were only occasionally caught in the late 1970s now make up 58\% of total landings (Schiller et al., 2014).

The bycatch estimates, biomasses and catch compositions obtained by this study might be seasonspecific or even variable over the years. Therefore, results may only be representative for the observed time in this study months (from February to May 2012). Additionally, not all of the Galapagos archipelago was monitored so there might be regional differences that are not considered in the current investigation. Hence, further investigations on a larger spatial scale and over a longer time period are recommended.

\section{Management suggestions}

As multispecies fisheries target many different species, the general goal of increasing the selectivity of a fishery may not always be appropriate. Instead, the focus may rather be on reducing the bycatch of overexploited, threatened and protected species (Gillett, 2011). Furthermore, negative effects such as post release mortality on threatened bycatch species should be minimized and measures should involve appropriate implementation costs and should not affect fishing operations negatively (Sales et al., 2010). Here, we suggest management regulations towards a more sustainable Galapagos multispecies handline fishery.

Unravelling the problem of fisheries' selectivity is often associated with the improvement of gear settings (Broadhurst, 2000; Bache, 2003). For example, the use of certain bait species was found to influence the bycatch of cod in the Northwest Atlantic haddock fishery (Ford, Rudolph \& Fuller, 2008). Fishers from the Galapagos handline fishery stated that bait species are not equally selective and that the 
401 use of yellowfin tuna (Thunnus albacares) as bait seems to be related to the bycatch of sharks

402 (Zimmerhackel, unpublished data). Also larger hook sizes have been proven to be more effective in 403 capturing larger size classes of targeted fish (Ralston, 1990) and post-release mortality of groupers were 404 found to be significantly lower when using circle hooks instead of J-hooks (Burns \& Kerr, 2008). We

405

406 407 408

409 410 411 therefore recommend experimental investigations into distinctive hook types, hook sizes and bait species in order to determine a gear setting that reduces the catch of unwanted species, sizes and post-release mortality, without negatively affecting the target catch.

Unfortunately, the lack of specific biological knowledge about the most exploited species of this fishery impedes a proper assessment of their population status. Therefore, critical life stages and spawning grounds of the main target species C. princeps, M. olfax, P. albomaculatus and P. clemensi should be assessed. Spatio temporal closures of spawning aggregations should be taken into consideration in future zonification and management plans because the protection of critical life stages can effectively reduce the impact on threatened species (Beets \& Friedlander, 1999; Lester \& Halpern, 2008; Afonso, Fontes \& Santos, 2011). The question of whether reducing or encouraging discards results in a more effective management of fisheries resources, is still under debate because regulations such as harvest restrictions, meant to protect target species, can rise the volume of discards (Diamond $\&$ Beukers-Stewart, 2011). However, the ultimate impact of bycatch on populations are influenced by the bycatch mortality (Davis, 2002). As groupers were proven to have a high post-release survivorship (Burns \& Kerr, 2008) we suggest the implementation of minimum and maximum catch sizes and the exclusion of undersized individuals from the usage as bait to reduce their fishing mortality before reaching first maturity. Illegal fishing activities in regulated fisheries (such as the lobster and sea cucumber fishery) in the history of the GMR show that management regulations are often not respected by fishers (Hearn, 2008). The effectiveness of the marine reserve should therefore be studied.

Furthermore, the suggested measures should be accompanied by plans to raise fishers' awareness about bycatch related concerns and their implications for the sustainability of fish stocks.

Contrary to a common concern raised by the fishers, the reduction of fishing pressure on threatened target species does not necessarily have to be accompanied by a reduction of income. For example, integrating more resilient, faster growing non-target species in landings has been successfully adopted in a number of fisheries worldwide (Lobo et al., 2010; Rodríguez-Preciado, Madrid-Vera \& Meraz- 
432 Sánchez, 2012). In the Mexican Pacific, bycatch species of the family Haemulidae such as Pomadasys 433 panamensis have become an important part of the commercial catch from the fisheries (Rodríguez434 Preciado, Madrid-Vera \& Meraz-Sánchez, 2012). The fact that many species which presently are 435 commonly consumed in the Galapagos handline fishery have often been discarded during last decades 436 indicates a certain flexibility and ability by the fishing sector and the consumer community to adapt to 437 changes in their environment. This demonstrates that there is hope that new target species such as 438 grunts (which together made up 51.1\% of the bycatch biomass) could be accepted by both the fishers and consumers. However, the integration of new target species should ideally be accompanied by stock assessments on harvested species to prevent overfishing and all potential management alternatives

441 should be evaluated on an ecological and socio-economic basis by including the main stakeholders and 442 fishers in the solution finding process (Usseglio, Schuhbauer \& Friedlander, 2014).

\section{Conclusions}

445 This information about bycatch of the Galapagos handline fishery revealed that this fishery targets a 446 fairly high number of species and is not selective for species or size classes. Most individuals are not 447 landed due to economic motivations, either because the species or the fish sizes are not marketable.

448 Regulatory discards were observed to a lesser extent, indicating that protected species are not discarded 449 very frequently. However, more than two thirds of interviewed fishers mentioned that they discard 450 sharks. A more concerning result was the high number of small sized individuals of some target 451 species, which mostly suffer bycatch mortality mainly because they are used as bait, which increases 452 their overall fishing mortality. Moreover, interviews revealed a historical change in the bycatch level 453 towards lower bycatch ratios that was explained by a diversification of the catch composition due to 454 the overexploitation of some commercial species. As it becomes more evident that the most exploited target species of this fishery are overfished (Burbano et al., 2014; Schiller et al., 2014) and to date there

456 457 458 459 460 461 462 are no regulations for any target species in place, our results demonstrate the need to integrate management measures in future management plans in order to minimize the fishing pressure on threatened and protected species.

\section{Acknowledgements}

We express our gratitude to the fishers associations, the "Unión de Cooperativas de Producción Pesquera Artesanales de Galápagos" (COPROPAG) and the "Unión de Cooperativas de Pesca de 
463 Galápagos" (UCOOPEPGAL) for their collaboration and all participating fishers who helped us 464 with their collaboration at sea and by sharing their knowledge during the interview surveys. We 465 are grateful to the Charles Darwin Research Station and the Galápagos National Park Services for 466 providing the necessary logistics. This publication is contribution number 2109 of the Charles 467 Darwin Foundation for the Galapagos Islands.

468

469 References

470 Afonso P, Fontes J, Santos RS. 2011. Small marine reserves can offer long term protection to an endangered 471 fish. Biological Conservation 144:2739-2744.

472

473

474

475

476

477

478

479

480

481

482

483

484

485 Coastal Management 46:103-125.

Beets J, Friedlander A. 1999. Evaluation of a conservation strategy: a spawning aggregation closure for red hind, Epinephelus guttatus, in the U.S. Virgin Islands. Environmental Biology of Fishes 55:91-98.

Berkes F. 2001. Managing Small-scale Fisheries: Alternative Directions and Methods. IDRC.

Bjorkland RH. 2011. An Assessment of Sea Turtle, Marine Mammal and Seabird Bycatch in the Wider Caribbean Region. DUKE UNIVERSITY.

Blaber SJM, Wassenberg TJ. 1989. Feeding ecology of the piscivorous birds Phalacrocorax varius, P. melanoleucos and Sterna bergii in Moreton Bay, Australia: diets and dependence on trawler discards. Marine Biology 101:1-10.

Bozzano A, Sardà F. 2002. Fishery discard consumption rate and scavenging activity in the northwestern Mediterranean Sea. ICES Journal of Marine Science: Journal du Conseil 59:15-28.

Broadhurst MK. 2000. Modifications to reduce bycatch in prawn trawls: A review and framework for development. Reviews in Fish Biology and Fisheries 10:27-60.

Burbano DV, Mena CF, Guarderas P, Vinueza L, Reck G. 2014. Shifting Baselines in the Galapagos White Fin Fishery, Using Fisher's Anecdotes to Reassess Fisheries Management: The Case of the Galapagos 
Grouper. In: Denkinger J, Vinueza L eds. The Galapagos Marine Reserve. Social and Ecological Interactions in the Galapagos Islands. Springer International Publishing, 227-246.

Burns RJ, Kerr GN. 2008. Observer effect on fisher bycatch reports in the New Zealand ling (Genypterus blacodes) bottom longlining fishery. New Zealand Journal of Marine and Freshwater Research 42:2332.

Bustamante RH. 1998. The artisan fishing sector of the Galápagos and the 1997 fishing season. Quito, Ecuador: WWF.

Castrejón Mendoza. 2011. Co-Manejo Pesquero en la R eserva Marina de Galápagos: Tendencias, Retos y Perspectivas de Cambio. Fundación Charles Darwin.

Chuenpagdee R, Liguori L, Palomares MLD, Pauly D. 2006. Bottom-up, global estimates of small-scale marine fisheries catches.

Chuenpagdee R. 2011. World Small-scale Fisheries: Contemporary Visions. Eburon Uitgeverij B.V.

Crowder LB, Murawski SA. 1998. Fisheries Bycatch: Implications for Management. Fisheries 23:8-17.

Danulat, Edgar. 2002. Marina de Galápagos. Línea Base de la Biodiversidad. Santa Cruz, Galápagos, Ecuador: Fundación Charles Darwin, Parque Nacional Galápagos.

Davies RWD, Cripps SJ, Nickson A, Porter G. 2009. Defining and estimating global marine fisheries bycatch. Marine Policy 33:661-672.

Davis MW. 2002. Key principles for understanding fish bycatch discard mortality. Canadian Journal of Fisheries and Aquatic Sciences 59:1834-1843.

Dayton PK, Thrush SF, Agardy MT, Hofman RJ. 1995. Environmental effects of marine fishing. Aquatic Conservation: Marine and Freshwater Ecosystems 5:205-232.

Denkinger J, Quiroga D, Murillo JC. 2014. Assessing Human-Wildlife Conflicts and Benefits of Galápagos Sea Lions on San Cristobal Island, Galápagos. In: Denkinger J, Vinueza L eds. The Galapagos Marine Reserve. Social and Ecological Interactions in the Galapagos Islands. Springer International Publishing, $285-305$. 
514 Diamond B, Beukers-Stewart BD. 2011. Fisheries Discards in the North Sea: Waste of Resources or a Necessary Evil? Reviews in Fisheries Science 19:231-245.

Ayora, Santa Cruz, Galapagos, Ecuador: Parque Nacional Galápagos, Ministério del Ambiente.

Dulvy NK, Sadovy Y, Reynolds JD. 2003. Extinction vulnerability in marine populations. Fish and Fisheries $4: 25-64$.

Dunn DC, Boustany AM, Halpin PN. 2011. Spatio-temporal management of fisheries to reduce by-catch and increase fishing selectivity. Fish and Fisheries 12:110-119.

Edgar GJ, Banks SA, Brandt M, Bustamante RH, Chiriboga A, Earle SA, Garske LE, Glynn PW, Grove JS, Henderson S, Hickman CP, Miller KA, Rivera F, Wellington GM. 2010. El Niño, grazers and fisheries interact to greatly elevate extinction risk for Galapagos marine species. Global Change Biology $16: 2876-2890$.

Ford JS, Rudolph T, Fuller SD. 2008. Cod bycatch in otter trawls and in longlines with different bait types in the Georges Bank haddock fishery. Fisheries Research 94:184-189.

Froese R, Binohlan C. 2000. Empirical relationships to estimate asymptotic length, length at first maturity and length at maximum yield per recruit in fishes, with a simple method to evaluate length frequency data. Journal of Fish Biology 56:758-773.

Froese R, Pauly D. 2000. Fishbase 2000. Fishbase 2000: concepts, design and data sources. WorldFish.

Gillett R. 2011. Bycatch in small-scale tune fisheries: a global study.

Goodman LA. 1961. Snowball Sampling. The Annals of Mathematical Statistics 32:148-170.

Grabowski JH, Clesceri EJ, Baukus AJ, Gaudette J, Weber M, Yund PO. 2010. Use of Herring Bait to Farm Lobsters in the Gulf of Maine. PLoS ONE 5:e10188.

Hall MA. 1999. Estimating the ecological impacts of fisheries: what data are needed to estimate bycatches?

Harrington JM, Myers RA, Rosenberg AA. 2005. Wasted fishery resources: discarded by-catch in the USA. Fish and Fisheries 6:350-361. 
539 Hearn A. 2008. The rocky path to sustainable fisheries management and conservation in the Galápagos Marine Reserve. Ocean \& Coastal Management 51:567-574.

541 Heylings P, Bensted-Smith R, Altamirano M. 2002. Capitulo 1: Zonificación e historia de a Reserva Marina de 542 Galápagos. In: Reserva Marina de Galápagos: Linea Base de la Biodiversidad. Fundación Charles

INEC. 2011. Proyecciones-poblacionales. Instituto Nacional de Estadísticas y Censos.

Jackson KM, Trochim WMK. 2002. Concept Mapping as an Alternative Approach for the Analysis of OpenEnded Survey Responses. Organizational Research Methods 5:307-336.

Jacquet J, Alava JJ, Pramod G, Henderson S, Zeller D. 2008. In hot soup: sharks captured in Ecuador's waters. Environmental Sciences 5:269-283.

Jacquet J, Pauly D. 2008. Funding Priorities: Big Barriers to Small-Scale Fisheries. Conservation Biology $22: 832-835$.

Johannes R e., Freeman M m. r., Hamilton R j. 2000. Ignore fishers' knowledge and miss the boat. Fish and Fisheries 1:257-271.

Kappel CV. 2005. Losing pieces of the puzzle: threats to marine, estuarine, and diadromous species. Frontiers in Ecology and the Environment 3:275-282.

Lester SE, Halpern BS. 2008. Biological responses in marine no-take reserves versus partially protected areas. Marine Ecology Progress Series 367:49-56.

Lewison RL, Crowder LB, Read AJ, Freeman SA. 2004. Understanding impacts of fisheries bycatch on marine megafauna. Trends in Ecology \& Evolution 19:598-604.

Lobo AS, Balmford A, Arthur R, Manica A. 2010. Commercializing bycatch can push a fishery beyond economic extinction. Conservation Letters 3:277-285.

McCluskey SM, Lewison RL. 2008. Quantifying fishing effort: a synthesis of current methods and their applications. Fish and Fisheries 9:188-200.

Moore JE, Cox TM, Lewison RL, Read AJ, Bjorkland R, McDonald SL, Crowder LB, Aruna E, Ayissi I, Espeut P, Joynson-Hicks C, Pilcher N, Poonian CNS, Solarin B, Kiszka J. 2010. An interview-based approach 
to assess marine mammal and sea turtle captures in artisanal fisheries. Biological Conservation 143:795-805.

Mora C, Myers RA, Coll M, Libralato S, Pitcher TJ, Sumaila RU, Zeller D, Watson R, Gaston KJ, Worm B. 2009. Management Effectiveness of the World's Marine Fisheries. PLoS Biol 7:e1000131.

Murray G, Neis B, Johnsen JP. 2006. Lessons Learned from Reconstructing Interactions Between Local Ecological Knowledge, Fisheries Science, and Fisheries Management in the Commercial Fisheries of Newfoundland and Labrador, Canada. Human Ecology 34:549-571.

Myers RA, Baum JK, Shepherd TD, Powers SP, Peterson CH. 2007. Cascading Effects of the Loss of Apex Predatory Sharks from a Coastal Ocean. Science 315:1846-1850.

National Marine Fisheries Service. 2004. Evaluating bycatch: A national approach to standardized bycatch monitoring programs. U.S. Department of Commerce, NOAA Technical Memorandum NMFS-F/SPO66:108.

National Marine Fisheries Service. 2011. U.S. National Bycatch Report. National Oceanic and Athmospheric Administration.

Nicolaides F, Murillo JC, Toral MV, Reck G. 2002. Capitulo 7: Bacalao. In: Reserva Marina de Galápagos: Linea Base de la Biodiversidad. Fundación Charles Darwin, Parque Nacional Galápagos, 146-165.

Ogle DH. 2013a. FSA: Fisheries Stock Analysis. R package version 0.3.5.

Parker RWR, Tyedmers PH. 2014. Fuel consumption of global fishing fleets: current understanding and knowledge gaps. Fish and Fisheries:n/a-n/a.

Pascoe S. 1997. Bycatch management and the economics of discarding.

Pauly D, Christensen V, Dalsgaard J, Froese R, Torres F. 1998. Fishing Down Marine Food Webs. Science 279:860-863.

Peñaherrera C, Hearn A. 2008. Toward an ecosystem-based approach to fisheries: a risk analysis. Puerto Ayora, Santa Cruz, Galapagos, Ecuador: Charles Darwin Foundation.

Ralston S. 1990. Size Selection of Snappers (Lutjanidae) by Hook and Line Gear. Canadian Journal of Fisheries and Aquatic Sciences 47:696-700. 
591 Reck GK. 1983. The coastal fisheries in the Galapagos Islands, Ecuador. Descriptions and Consequences for 592 Management in the Context of Marine Environmental Protection and Regional Development. Kiel, 593 Germany: Christian-Albrecht-Universität Kiel.

594 Robertson R, Allen G, Dominici-Arosemena A, Edgar GJ, Rivera F, Merlen G. 2010. Paralabrax albomaculatus. $595 \quad$ IUCN Red List of Threatened Species.

596 Rodríguez-Preciado JA, Madrid-Vera J, Meraz-Sánchez R. 2012. Size Structure and Biomass of the Panama 597 Grunt (Pomadasys panamensis) from Bycatch in the Southeastern Gulf of California. Open Journal of $598 \quad$ Marine Science 2:1-7.

599 Ruttenberg BI. 2001. Effects of Artisanal Fishing on Marine Communities in the Galápagos Islands.

600 Conservation Biology 15:1691-1699.

601 Ryer CH, Ottmar ML, Sturm EA. 2004. Behavioral impairment after escape from trawl codends may not be 602 603 604 605 606 limited to fragile fish species. Fisheries Research 66:261-269.

Saila SB, Nixon SW, Oviatt CA. 2002. Does Lobster Trap Bait Influence the Maine Inshore Trap Fishery? North American Journal of Fisheries Management 22:602-605.

Sales G, Giffoni BB, Fiedler FN, Azevedo VG, Kotas JE, Swimmer Y, Bugoni L. 2010. Circle hook effectiveness for the mitigation of sea turtle bycatch and capture of target species in a Brazilian pelagic longline fishery. Aquatic Conservation: Marine and Freshwater Ecosystems 20:428-436.

Schiller L, Alava JJ, Grove J, Reck G, Pauly D. 2014. The demise of Darwin's fishes: evidence of fishing down and illegal shark finning in the Galápagos Islands. Aquatic Conservation: Marine and Freshwater Ecosystems:n/a-n/a.

Shester GG, Micheli F. 2011. Conservation challenges for small-scale fisheries: Bycatch and habitat impacts of traps and gillnets. Biological Conservation 144:1673-1681.

613 Soykan, Moore, Zydelis, Crowder, Safina, Lewison. 2008. Why study bycatch? An introduction to the theme section on fisheries bycatch. Endangered Species Research 5:91-102.

615 Teh LCL, Sumaila UR. 2013. Contribution of marine fisheries to worldwide employment. Fish and Fisheries $616 \quad 14: 77-88$. 
617 Usseglio P, Schuhbauer A, Friedlander A. 2014. Collaborative Approach to Fisheries Management as a Way to 618 Increase the Effectiveness of Future Regulations in the Galapagos Archipelago. In: Denkinger J, 619 Vinueza L eds. The Galapagos Marine Reserve. Social and Ecological Interactions in the Galapagos 620 Islands. Springer International Publishing, 187-202.

621 Wassenberg T, Hill B. 1990. Partitioning of material discarded from Prawn Trawlers in Morton Bay. Marine $622 \quad$ and Freshwater Research 41:27-36.

623 Wolff M, Schuhbauer A, Castrejón M. 2012. A revised strategy for the monitoring and management of the 624 Galapagos sea cucumber Isostichophus fuscus (Aspidochirotida: Stichopodidae). International Journal $625 \quad$ of Tropical Biology 60:539-551.

626 627 


\section{1}

Geographic position of the study site in the Galapagos Marine Reserve

Geographic position of the study site with the fishing ports (stars) and the monitored fishing sites (dots).

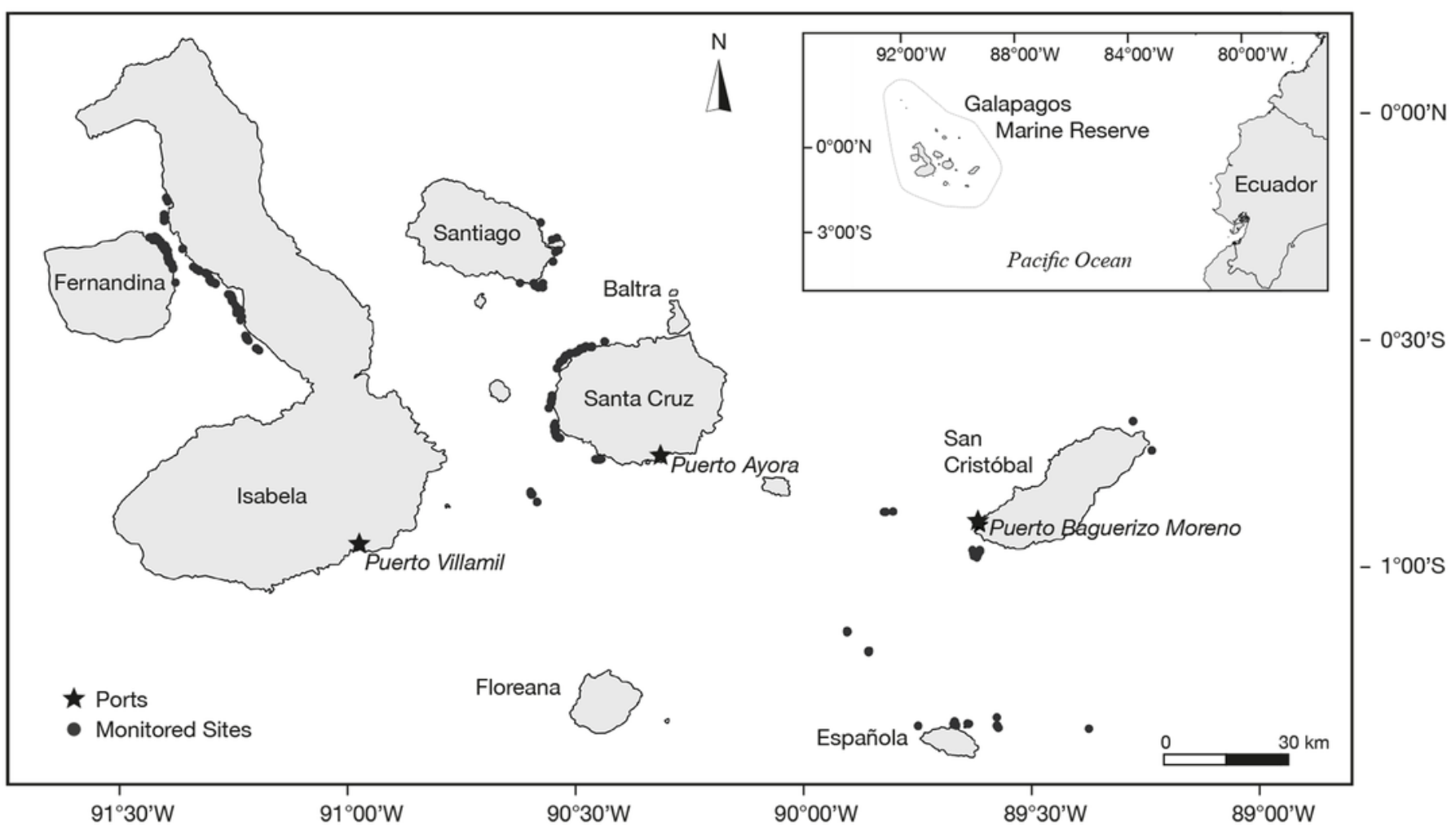


2

Catch categories and their fractions of the total catch biomass.

Fraction of the total biomass for landings and bycatch (outer circle) and the fractions of the according subcategories (inner circle) for landings (dashed green): personal use (dark green) and sold (light green), and for bycatch (dashed blue): bycatch mortality (dark blue) and dis carded alive (light blue). The bycatch mortality is divided by the fraction discarded dead and the fraction used as bait.

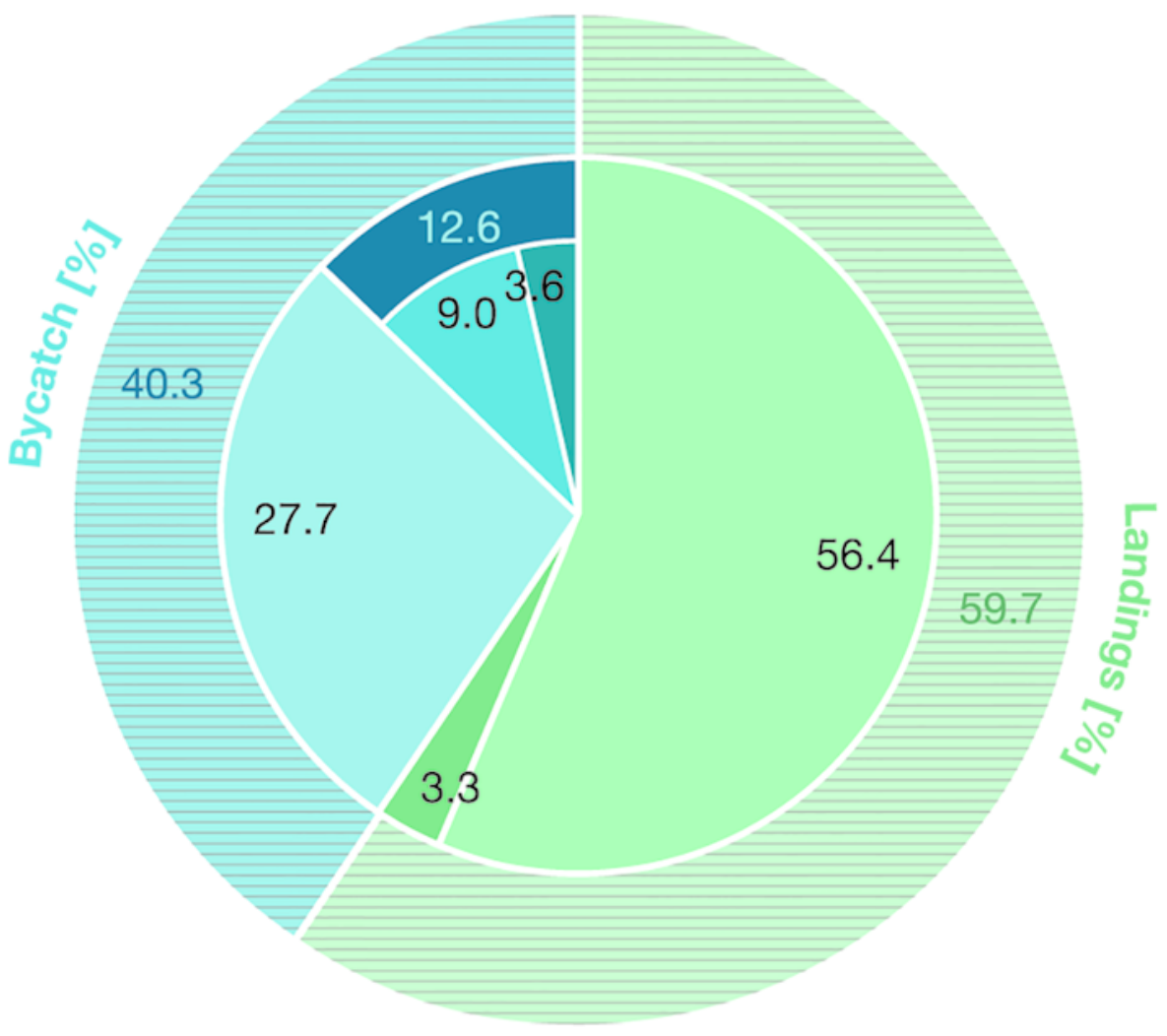

Bycatch mortality

Discarded dead

Bait

Discarded alive

Personal use

Sold 


\section{3}

Logistic regression model results showing the probability of an individual to belong to bycatch or to landings depending on the individuals' total length.

Shows the probability of an individual to belong to bycatch (0) or to landings (1) depending on the individuals' total length. The dashed blue line indicates the b80, the dashed grey line indicates the mean size of first maturity (Lm) of the species: a) C. princeps $(n=112, b 80=$ $42.7 \mathrm{~cm} \mathrm{TL}, \mathrm{Lm}=61.6 \mathrm{~cm} \mathrm{TL}$, odds ratio $=1.16) ; \mathrm{b})$ P. albomaculatus $(\mathrm{n}=112, \mathrm{~b} 80=39.2$ $\mathrm{cm} \mathrm{TL}, \mathrm{Lm}=36.3 \mathrm{~cm} \mathrm{TL}$, odds ratio $=1.24) ; \mathrm{c})$ P. clemensi $(\mathrm{n}=141, \mathrm{~b} 80=38.2 \mathrm{~cm} \mathrm{TL}, \mathrm{Lm}$ $=38.8 \mathrm{~cm} \mathrm{TL}$, odds ratio $=3.25 \mathrm{e}-7$ ). 
a

Caulolatilus princeps

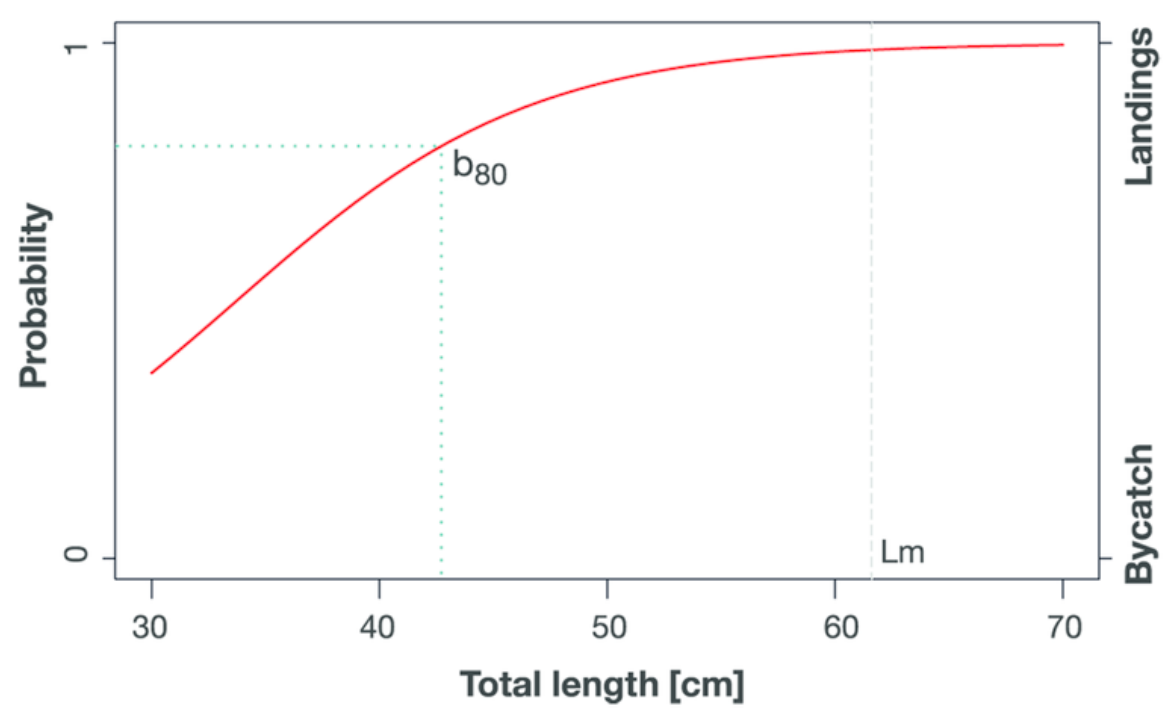

$\boldsymbol{b}$

Paralabrax albomaculatus
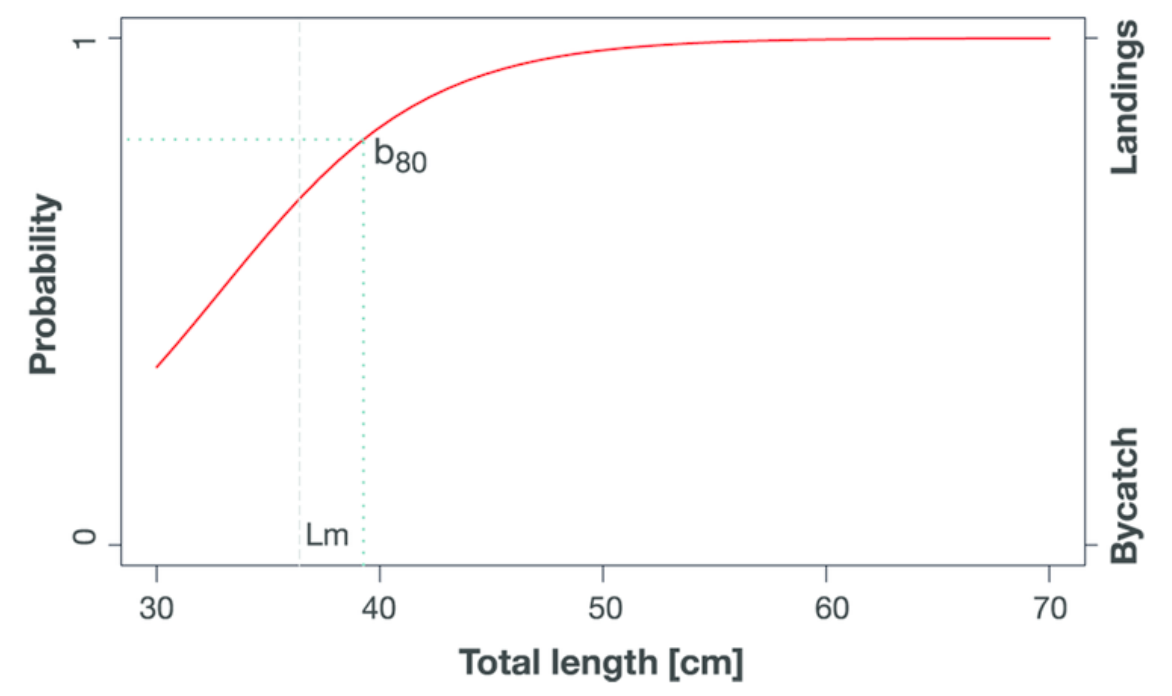

C

Pontinus clemensi

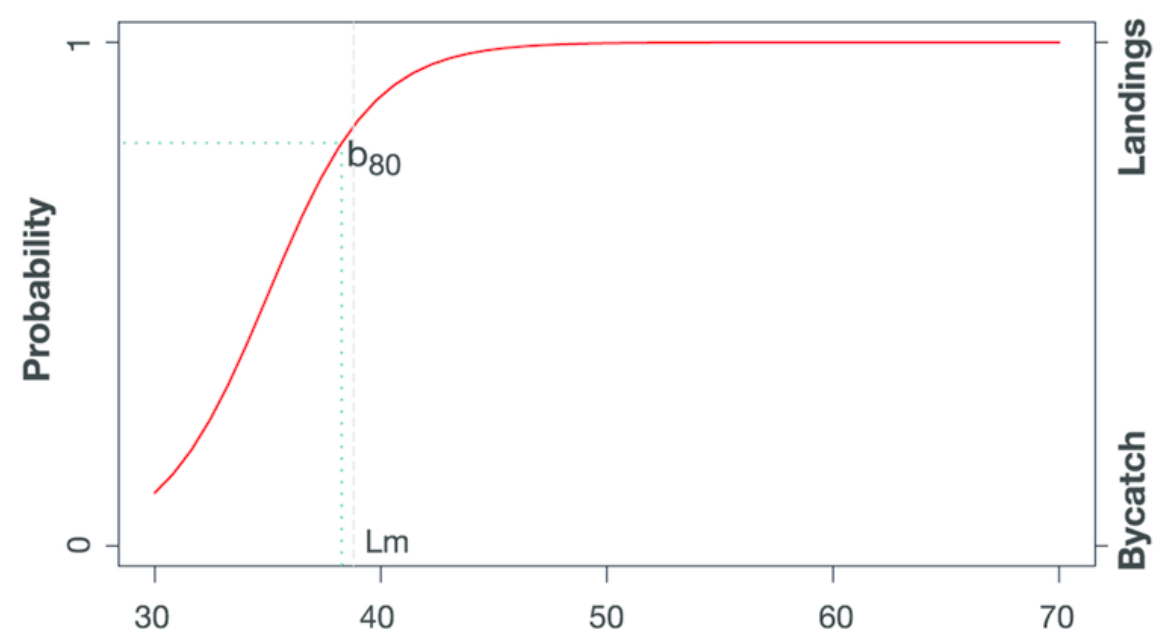

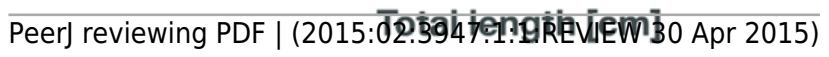


4

Percentage of responses of interviewees $(n=100)$ for each mentioned taxa as well as the reasons of fishers to not land these taxa.

Reasons to not land taxa are unmarketable species (dark blue), unmarketable size (light blue) and regulatory discard (green).

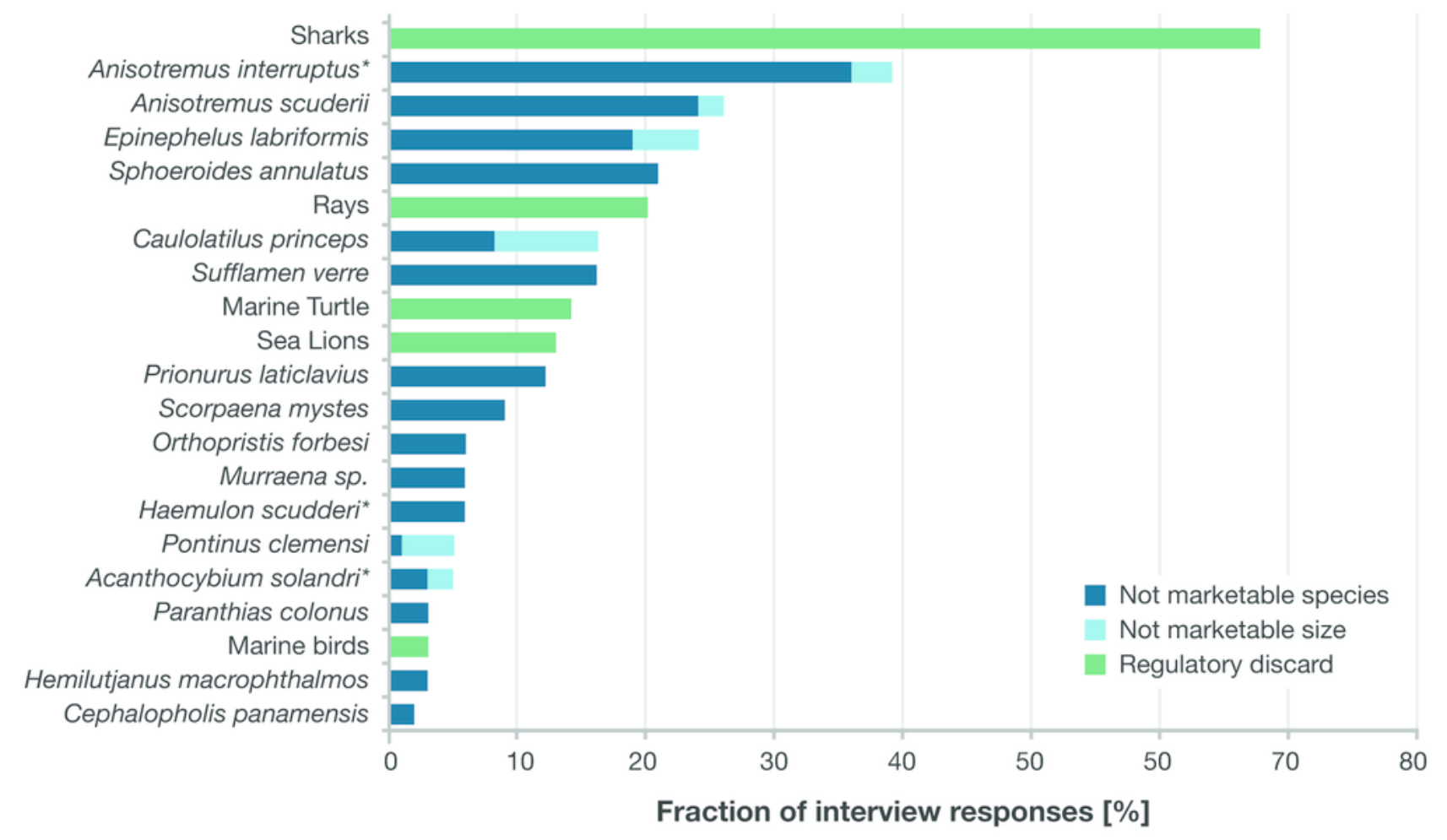




\section{Table $\mathbf{1}$ (on next page)}

Marketable species that were landed during onboard monitoring

Shows the numbers of individuals landed (N), their average total length with its' standard deviations (Av. TL $\pm S D$ ) and the bycatch ratio of each particular species (BCRs). Asterisks denote endemic species to Galapagos. 


\begin{tabular}{lllrrr} 
& & & & Av. TL \pm \\
Family & Scientific Name & Common Name & N & BCRs \\
\hline Serranidae & Mycteroperca olfax* & Galapagos sailfin grouper & 368 & $45.9 \pm 8.5$ & 0 \\
Serranidae & Cratinus agassizi & Grazery threadfin seabass & 16 & $59.8 \pm 11.5$ & 0 \\
Serranidae & Epinephelus mystacinus & Misty Grouper & 2 & $83.0 \pm 5.0$ & 0 \\
Carangidae & Caranx caballus & Green jack & 1 & $49.0 \pm 0.0$ & 0 \\
Lutjanidae & Hoplopagrus guentheri & Barred Snapper & 1 & $72.0 \pm 0.0$ & 0 \\
Labridae & Semicossyphus darwini & Galapagos sheephead wrasse & 37 & $51.4 \pm 7.4$ & 0.08 \\
Malacanthidae & Caulolatilus princeps & Ocean whitefish & 88 & $42.5 \pm 5.0$ & 0.21 \\
Serranidae & Paralabrax albomaculatus* & Camotillo & 85 & $44.9 \pm 7.5$ & 0.24 \\
Scorpaenidae & Pontinus clemensi* & Mottled scorpionfish & 106 & $45.3 \pm 7.4$ & 0.25 \\
Sparidae & Calamus taurinus* & Galapagos porgy & 6 & $38 \pm 4.1$ & 0.25 \\
Malacanthidae & Caulolatilus affinis & Bighead tilefish & 2 & $48.5 \pm 3.5$ & 0.33 \\
Serranidae & Hemilutjanus macrophthalmos & Grape eye seabass & 3 & $58.3 \pm 1.3$ & 0.4 \\
Carangidae & Caranx sexfasciatus & Bigeye trevally & 1 & $46.0 \pm 0.0$ & 0.5 \\
Serranidae & Epinephelus cifuentesi & Olive grouper & 2 & $64.5 \pm 21.5$ & 0.6 \\
Serranidae & Epinephelus labriformis & Starry grouper & 6 & $38.7 \pm 3.0$ & 0.89 \\
Haemulidae & Anisotremus scuderii & Peruvian grunt & 6 & $31.3 \pm 3.1$ & 0.93 \\
Haemulidae & Anisotremus interruptus & Burrito grunt & 3 & $32.3 \pm 2.1$ & 0.98 \\
\hline
\end{tabular}


Table 2 (on next page)

Not marketable species, not marketable sizes and regulatory discards that were recorded during onboard monitoring,

Shows numbers of specimens (N), their average total length with its' standard deviations (Av. $\mathrm{TL} \pm \mathrm{SD}$ ) and the bycatch ratio of each particular species (BCRs). Asterisks denote endemic species to Galapagos. 


\begin{tabular}{|c|c|c|c|c|c|}
\hline Family & Scientific name & Common name & $\mathbf{N}$ & $\begin{array}{r}\text { Av. TL } \\
{[\mathrm{cm}] \pm \text { SD }}\end{array}$ & BCRs \\
\hline \multicolumn{6}{|c|}{ Not marketable species } \\
\hline Haemulidae & Haemulon sexfasciatum & Greybar grunt & 29 & $30.0 \pm 4.9$ & 1 \\
\hline Lutjanidae & Lutjanus viridis & Blue and gold snapper & 19 & $26.2 \pm 3.6$ & 1 \\
\hline Serranidae & Paranthias colonus & Pacific creolefish & 17 & $30.6 \pm 4.3$ & 1 \\
\hline Sphyraenidae & Sphyraena idiastes & Pelican barracuda & 11 & $59.3 \pm 9.9$ & 1 \\
\hline Haemulidae & Haemulon scudderi* & Grey grunt & 6 & $32.0 \pm 3.5$ & 1 \\
\hline Balistidae & Balistes polylepis & Finescale triggerfish & 5 & $45.6 \pm 1.0$ & 1 \\
\hline Balistidae & Sufflamen verres & Orangeside triggerfish & 5 & $37.4 \pm 5.2$ & 1 \\
\hline Scorpaenidae & Scorpaena mystes & Pacific spotted scorpionfish & 2 & $28.0 \pm 0.0$ & 1 \\
\hline Synodontidae & Synodus lacertinus & Banded lizardfish & 2 & $34.0 \pm 7.0$ & 1 \\
\hline Kyphosidae & Girella freminvilli & Dusky chub & 1 & $35.0 \pm 0.0$ & 1 \\
\hline Muraenidae & Murraena sp. & Moray eel & 1 & $60.0 \pm 0.0$ & 1 \\
\hline Scombridae & Scomberomorus sierra & Pacific Sierra & 1 & $90.0 \pm 0.0$ & 1 \\
\hline Scorpaenidae & Scorpaena histrio & Bandfin scorpionfish & 1 & $33.0 \pm 0.0$ & 1 \\
\hline Serranidae & Serranus psittacus & Barred serrano & 1 & $13.0 \pm 0.0$ & 1 \\
\hline Tetradontidae & Sphoeroides annulatus & Bullseye puffer & 1 & $27.0 \pm 0.0$ & 1 \\
\hline Haemulidae & Anisotremus interruptus* & Burrito grunt & 191 & $33.2 \pm 5.0$ & 0.98 \\
\hline Haemulidae & Anisotremus scuderii & Peruvian grunt & 81 & $32.2 \pm 2.9$ & 0.93 \\
\hline Malacanthidae & Caulolatilus affinis & Bighead tilefish & 3 & $45.7 \pm 4.5$ & 0.33 \\
\hline \multicolumn{6}{|c|}{ Not marketable size } \\
\hline Serranidae & Dermatolepis dermatolepis & Leather bass & 1 & $46.0 \pm 0.0$ & 1 \\
\hline Serranidae & Epinephelus labriformis & Starry grouper & 51 & $36.2 \pm 3.8$ & 0.89 \\
\hline Serranidae & Epinephelus cifuentesi & Olive grouper & 3 & $35.0 \pm 4.1$ & 0.6 \\
\hline Carangidae & Caranx sexfasciatus & Bigeye trevally & 1 & $43.0 \pm 0.0$ & 0.5 \\
\hline Serranidae & $\begin{array}{l}\text { Hemilutjanus } \\
\text { macrophthalmos }\end{array}$ & Grape eye seabass & 2 & $49.0 \pm 1.0$ & 0.4 \\
\hline Scorpaenidae & Pontinus clemensi* & Mottled scorpionfish & 35 & $31.2 \pm 5.3$ & 0.25 \\
\hline Sparidae & Calamus taurinus* & Galapagos porgy & 2 & $36.5 \pm 6.5$ & 0.25 \\
\hline Serranidae & Paralabrax albomaculatus* & Camotillo & 27 & $36.2 \pm 6.1$ & 0.24 \\
\hline Malacanthidae & Caulolatilus princeps & Ocean whitefish & 24 & $38.3 \pm 6.1$ & 0.21 \\
\hline Labridae & Semicossyphus darwini & $\begin{array}{l}\text { Galapagos sheephead } \\
\text { wrasse }\end{array}$ & 3 & $43.0 \pm 5.0$ & 0.08 \\
\hline \multicolumn{6}{|c|}{ Regulatory discard } \\
\hline Carcharhinidae & Carcharhinus galapagensis & Galapagos shark & 23 & $74.4 \pm 8.4$ & 1 \\
\hline Carcharhinidae & Triaenodon obesus & Whitetip reef shark & 3 & $110.0 \pm 0.0$ & 1 \\
\hline Otariidae & Zalophus wollebaeki & Californian sea lion & 2 & n.a. & 1 \\
\hline
\end{tabular}

